\title{
Photosynthetic responses of the coral Montipora digitata to cold temperature stress
}

\author{
Tracey Saxby ${ }^{1,3, *}$, William C. Dennison ${ }^{1}$, Ove Hoegh-Guldberg ${ }^{2}$ \\ ${ }^{1}$ School of Life Sciences, and ${ }^{2}$ Centre for Marine Studies, University of Queensland, Brisbane, Queensland 4072, Australia \\ ${ }^{3}$ Present address: University of Maryland Centre for Environmental Science, PO Box 775, Cambridge, Maryland 21613, USA
}

\begin{abstract}
Coral bleaching events have become more frequent and widespread, largely due to elevated sea surface temperatures. Global climate change could lead to increased variability of sea surface temperatures, through influences on climate systems, e.g. El Niño Southern Oscillation (ENSO). Field observations in 1999, following a strong ENSO, revealed that corals bleached in winter after unusually cold weather. To explore the basis for these observations, the photosynthetic responses of the coral species Montipora digitata Studer were investigated in a series of temperature and light experiments. Small replicate coral colonies were exposed to ecologically relevant lower temperatures for varying durations and under light regimes that ranged from darkness to full sunlight. Photosynthetic efficiency was analyzed using a pulse amplitude modulated (PAM) fluorometer $\left(F_{0}, F_{\mathrm{m}}, F_{\mathrm{v}} / F_{\mathrm{m}}\right)$, and chlorophyll a $(\mathrm{chl} a)$ content and symbiotic dinoflagellate density were analyzed with spectrophotometry and microscopy, respectively. Cold temperature stress had a negative impact on $M$. digitata colonies indicated by decreased photosynthetic efficiency $\left(F_{\mathrm{v}} / F_{\mathrm{m}}\right)$, loss of symbiotic dinoflagellates and changes in photosynthetic pigment concentrations. Corals in higher light regimes were more susceptible to cold temperature stress. Moderate cold stress resulted in photoacclimatory responses, but severe cold stress resulted in photodamage, bleaching and increased mortality. Responses to cold temperature stress of $M$. digitata appeared similar to that observed in corals exposed to warmer than normal temperatures, suggesting a common mechanism. The results of this study suggest that corals and coral reefs may also be impacted by exposure to cold as well as warm temperature extremes as climate change occurs.
\end{abstract}

KEY WORDS: Coral bleaching $\cdot$ Photosynthesis $\cdot$ Climate change $\cdot$ Photoinhibition $\cdot F_{\mathrm{v}} / F_{\mathrm{m}} \cdot$ Cold temperature stress $\cdot$ Symbiotic dinoflagellates

\section{INTRODUCTION}

Coral bleaching is a response by corals to stressful conditions (Yonge \& Nicholls 1931, Hoegh-Guldberg \& Smith 1989a, Fang et al. 1997, Jones et al. 1998, HoeghGuldberg \& Jones 1999) and has been observed following various physical and chemical changes to the environment, both in the laboratory and in the field (Yonge \& Nicholls 1931, Reimer 1971, Jokiel \& Coles 1974, Kleppel et al. 1989). Factors reported to induce bleaching include temperature, light and salinity as well as chemical factors like cyanide and herbicides. Bleaching involves the dissociation of the symbiosis between corals and their symbiotic dinoflagellates. There is a loss of pigmentation

*Email: tracey_saxby@yahoo.com due to decreased numbers of symbiotic dinoflagellates, a reduction in photosynthetic pigments or both (Yonge \& Nicholls 1931, Hoegh-Guldberg 1989, Kleppel et al. 1989, Porter et al. 1989, Jokiel \& Coles 1990).

The first anecdotal reports of coral bleaching occurred in the 1870s (Glynn 1993, Brown 1997a). Over the last decade, however, reports of coral bleaching have increased in frequency and scale (Gates et al. 1992, Brown et al. 1994). The majority of reported bleaching events have been correlated with elevated sea surface temperatures (Hoegh-Guldberg 1999). Several studies indicate that elevated temperatures act to increase the susceptibility of the symbiotic dinoflagellates of corals to photoinhibition, with the resulting damage leading to 
expulsion from the coral host (Lesser et al. 1990, Roberts 1990, Iglesias-Prieto et al. 1992, Hoegh-Guldberg \& Jones 1999). However, localized spatial variability and differences both within and between species suggest that other factors may also influence coral bleaching (Brown 1997a, Berkelmans \& Willis 1999).

The susceptibility of corals to temperature stress has taken on particular significance in the context of global warming, and the occurrence of world wide bleaching events has attracted considerable political, social and scientific comment (Williams \& Bunkley-Williams 1990, Buss \& Vaisnys 1993, Glynn 1993, Hoegh-Guldberg 1999). Observed temperature responses of corals suggest they are living very close to their upper thermal limits (Jokiel \& Coles 1990, Lesser 1997), prompting concern that increasing global temperatures, in conjunction with El Niño Southern Oscillation (ENSO) events, could have a dramatic influence on reef communities. The observation that sea temperatures have increased by almost $1^{\circ} \mathrm{C}$ over the past 100 yr has been suggested as an underlying reason why corals exist so close to their thermal limit. Projected changes in sea temperature (based on several general circulation models) indicate in all cases that sea temperatures will rise above those known to be tolerated by reef building corals (Hoegh-Guldberg 1999).

Bleaching has also been correlated with decreases in sea surface temperatures (Coles \& Jokiel 1977, Gates et al. 1992, O. Hoegh-Guldberg pers. obs.) and has been reported in laboratory studies of symbiotic sea anemones (Steen \& Muscatine 1987). The geographic limits of corals are also thought to be set by a lower temperature limit of $18^{\circ} \mathrm{C}$ (Dana 1843, Vaughan 1918), with a few exceptions penetrating the colder waters (Keven \& Hudson 1979, Coles \& Fadlallah 1991). Changing intensities as well as frequencies of ENSO events in the Pacific (Urban et al. 2000) suggest that La Niña events (super normal conditions) may increase in frequency. La Niña events tend to be associated with colder, wetter years in which sea temperatures can be cooler than long-term averages. Different wind patterns will also drive local scale effects. The passage of polar continental air masses have been shown to have rapid cooling effects on shallow water carbonate environments, with chilling and mixing of water bodies augmented by associated strong winds (Roberts et al. 1982). Upwelling may also affect open ocean reefs, with temperatures dropping several degrees with the changing of tides (Glynn \& Stewart 1973). The greatest daily temperature ranges (commonly 6 to $14^{\circ} \mathrm{C}$ ) have been recorded in shallow reef flat environments (Orr 1933, Wells 1952, Endean et al. 1956, Brown 1997b).

The present study explored the effect of cold stress on the physiology of the coral Montipora digitata Studer and its symbiotic dinoflagellates, after observa- tions of bleaching in this species and others following the cold conditions of winter in 1999. Changes in key physiological parameters such as the photochemical efficiency $\left(F_{\mathrm{v}} / F_{\mathrm{m}}\right)$ were measured, which has been found to be central to responses of phototrophic organisms to elevated thermal stress. Other key parameters that provide an insight into the physiological response of corals to cold stress include the density of symbiotic dinoflagellates and concentrations of their photosynthetic pigments. Initial experiments were conducted to investigate how the duration of exposure affected responses to colder than ambient temperatures. The potential for recovery of photosynthetic efficiency following temperature stress was examined, over shortand long-term periods. The synergistic effects of light and temperature in causing an increased sensitivity to photoinhibition were also investigated.

\section{MATERIALS AND METHODS}

Study site. Small replicate branches (nubbins) of the scleractinian coral Montipora digitata were collected from the southern reef flat at Heron Island, Australia $\left(23^{\circ} 26^{\prime} 47.5^{\prime \prime} \mathrm{S}, 151^{\circ} 54^{\prime} 41.2^{\prime \prime} \mathrm{E}\right)$. Coral nubbins (2 to $3 \mathrm{~cm}$ in length) were removed from 20 colonies of $M$. digitata growing on the reef flat using long-nosed pliers. Ten to 15 nubbins were collected from the upper surfaces of each colony.

Following collection, each coral nubbin was mounted in the lids of scintillation vials using non-toxic modeling clay and then placed within aquaria. This technique has been successfully used in a number of physiological studies of reef-building corals (e.g. HoeghGuldberg \& Jones 1999, Jones et al. 1999). Corals were left to adapt to aquaria conditions for $7 \mathrm{~d}$ to minimize the influence of stress due to collection and nubbin preparation. Both field and handling controls were measured whenever fresh corals were collected to determine whether handling caused any significant differences in the measured parameters.

Experimental design. Maintenance of experimental aquaria: Four treatment tanks were established and temperatures were maintained to within $\pm 0.5^{\circ} \mathrm{C}$ of the desired treatment. Each tank consisted of 3 chambers containing aerated seawater. Two tanks were connected to a water bath (Grant LTD6) that recirculated cooled water around the outside of the chambers. The other 2 tanks received ambient seawater from the reef flat around the outside of the chambers $\left(23\right.$ to $26^{\circ} \mathrm{C}$ seasonally dependent). Daily fluctuations were within $\pm 0.5^{\circ} \mathrm{C}$. The different temperature treatments were conducted on different days, each with a corresponding control treatment. Coral nubbins were maintained at a set orientation throughout the experiments. Fol- 
lowing treatment in all experiments, nubbins were returned to ambient temperatures and photosynthetic efficiency $\left(F_{\mathrm{v}} / F_{\mathrm{m}}\right)$ was monitored daily for $3 \mathrm{~d}$ at the same time each day. Following the monitoring period, nubbins were immediately frozen for further laboratory analysis of chlorophyll a ( $\mathrm{chl}$ a) concentration and dinoflagellate density.

Time course of cold temperature response: Nubbins were randomly assigned to 1 of 3 different temperature regimes $\left(12,16\right.$ or $\left.20^{\circ} \mathrm{C}\right)$ or an ambient temperature control $\left(23^{\circ} \mathrm{C}\right)$. Experiments commenced at 08:00 h each day and terminated at $02: 00 \mathrm{~h}$ the following day. Three replicate nubbins were randomly removed from each treatment at 1, 3, 6, 12 and $18 \mathrm{~h}$ following commencement of the experiment.

Synergistic effects of light and temperature: Corals were randomly assigned to 1 of 3 temperature treatments $\left(14,20\right.$ or $\left.26^{\circ} \mathrm{C}\right)$. Three different irradiance regimes $(100,50$ and $0 \%$ of incident light) were used within each temperature treatment. Irradiance was provided by natural sunlight and $100 \%$ light was equivalent to 1200 to $1450 \mu \mathrm{m} \mathrm{m}^{-2} \mathrm{~s}^{-1}$. Corals were exposed to these temperature and light treatments for $6 \mathrm{~h}$ from 12:00 to 18:00 h. Respective light regimes were maintained for the entire period.

Chl a fluorescence measurements: Chl a fluorescence was measured using a pulse amplitude modulated (PAM) fluorometer (DIVING-PAM) (Schreiber et al. 1986). The DIVING-PAM was used to measure the minimal $\left(F_{0}\right)$ and maximal $\left(F_{\mathrm{m}}\right)$ fluorescence yields. Variable fluorescence $\left(F_{\mathrm{v}}\right)$ was calculated as $F_{\mathrm{m}}-F_{0}$, and maximum potential quantum yield as $F_{\mathrm{v}} / F_{\mathrm{m}}$. The dark-adapted quantum yield $\left(F_{\mathrm{v}} / F_{\mathrm{m}}\right.$, Schreiber et al. 1986), provides a good approximation of the maximum photochemical efficiency of Photosystem II (PSII) (Björkman \& Demmig 1987, Schreiber \& Neubauer 1990, Öquist et al. 1992). Measurements were taken following a dark-adaptation period of $30 \mathrm{~min}$, which allows enough time for relaxation of photoprotection in corals (Jones \& Hoegh-Guldberg 1999). During measurements, the fibre-optic cable of the fluorometer was maintained approximately $1 \mathrm{~mm}$ from the coral surface. Measurements were taken at the base of each colony on the side facing directly north during the experimental incubation.

Determination of chl content and density of symbiotic dinoflagellates: Coral tissues were stripped from the skeleton with a jet of re-circulated filtered seawater using an oral irrigator (WaterPik ${ }^{\mathrm{TM}}$ ). The resulting slurry was homogenized with a blender for $30 \mathrm{~s}$ and the volume of the homogenate was recorded $(\sim 100 \mathrm{ml})$. A $10 \mathrm{ml}$ aliquot of the homogenate slurry was preserved with $1 \mathrm{ml}$ formalin and the density of symbiotic dinoflagellates was determined by using 8 replicate counts on a hemocytometer. After correcting for homogenate volume and surface area of the coral branch, the densities of symbiotic dinoflagellates were determined and expressed per unit surface area.

Three $10 \mathrm{ml}$ aliquots of homogenate were taken to determine content of chls $a, b$ and $c$. Samples were centrifuged for $5 \mathrm{~min}$ at $3000 \mathrm{rpm}(2000 \times g)$ and the supernatant was discarded, leaving an algal pellet. The samples were resuspended with acetone and placed in a freezer $\left(-20^{\circ} \mathrm{C}\right)$ for $24 \mathrm{~h}$. Samples were centrifuged again at $3000 \mathrm{rpm}(2000 \times g)$ for $5 \mathrm{~min}$ and the absorbances of the supernatant were determined at $664,647,630$ and $750 \mathrm{~nm}$ on a spectrophotometer (Pharmacia LKB Ultraspec III) to determine chls $a, b$ and $C$, and turbidity, respectively. The absorbances at 664 and $750 \mathrm{~nm}$ were recorded following acidification with $10 \% \mathrm{HCl}$ to determine phaeophytin concentration. Concentrations of chl were calculated using equations of Jeffrey \& Humphrey (1975) after correcting for homogenate volume and the surface area of the coral samples.

Determination of surface area: Surface area was determined using melted wax maintained at $65^{\circ} \mathrm{C}$ in a water bath. Nubbins were dipped in the melted wax for a standard period of time $(5 \mathrm{~s})$. When set, the nubbin was weighed then dipped again into the wax $(5 \mathrm{~s})$. The difference between the first and second weight allows the surface area to be calculated by comparison with standardized cubes of known surface area (Jones et al. 2000).

Statistical analyses. A 2-way ANOVA with fixed effects was conducted on STATISTICA ${ }^{\odot}$ software (StatSoft) to determine differences between treatments for photosynthetic pigment analyses, counts of symbiotic dinoflagellates and measurements of photosynthetic efficiency $\left(F_{\mathrm{v}} / F_{\mathrm{m}}\right)$. Before analysis, Cochran's test was used to determine the homogeneity of variances and data were then log transformed when required, resulting in homogeneous or near-homogeneous samples (Eisenhart et al. 1947). Square-root transformations were applied when the group variances were proportional to the means (Zar 1984). When ANOVA determined a significant difference, Tukey's post hoc test was used to attribute differences between specific treatments (Zar 1984).

\section{RESULTS}

Time course of response to cold temperature stress

$$
\text { Photosynthetic efficiency }
$$

There were no significant differences in $F_{0}, F_{\mathrm{m}}$ or $F_{\mathrm{v}} / F_{\mathrm{m}}$ between control treatments conducted on 3 different days $(p>0.05)$. Results from the different control 


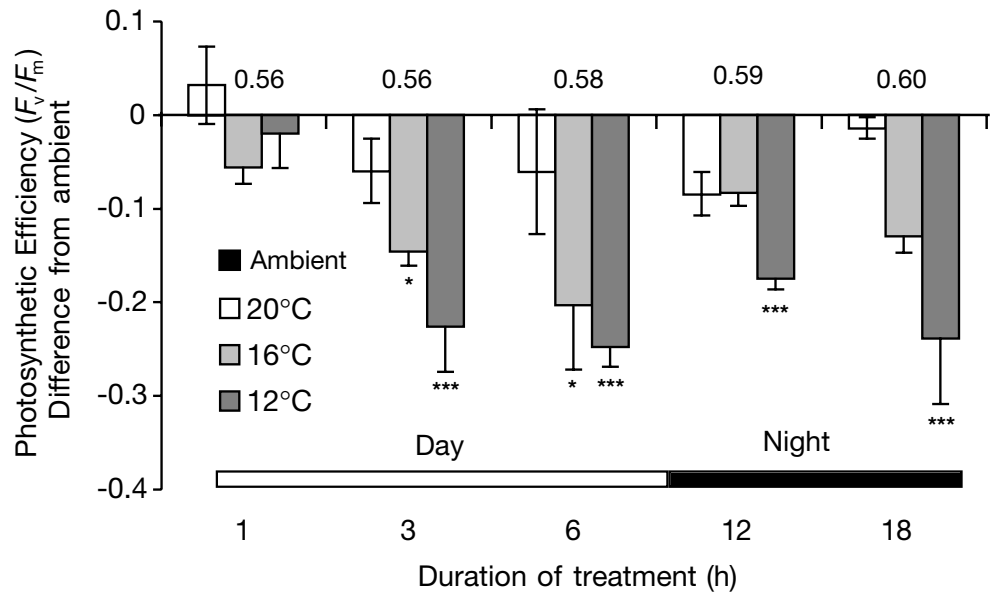

Fig. 1. Montipora digitata. Difference in photosynthetic efficiency $\left(F_{\mathrm{v}} / F_{\mathrm{m}}\right)$ of the coral Montipora digitata immediately following exposure to 1 of 4 temperature treatments $\left(23\right.$ [ambient], 20, 16 or $\left.12^{\circ} \mathrm{C}\right)$ of varying duration $(1,3,6,12$ or $18 \mathrm{~h})$. The bar represents the day/night cycle. Numbers on the $x$-axis are the mean $F_{\mathrm{v}} / F_{\mathrm{m}}$ at ambient temperatures. ${ }^{*} \mathrm{p}<0.05,{ }^{* *} \mathrm{p}<0.01,{ }^{* * *} \mathrm{p}<0.001$

treatments were therefore pooled. This also indicated that the different temperature treatments, while conducted on different days with different light regimes, could be directly compared. There was no immediate effect on $F_{\mathrm{v}} / F_{\mathrm{m}}$ after $1 \mathrm{~h}$ exposure to any temperature treatment. However, following $3 \mathrm{~h}$ exposure to decreased temperatures, $F_{\mathrm{v}} / F_{\mathrm{m}}$ declined by $0.06,0.15$ and 0.22 in the 20,16 and $12^{\circ} \mathrm{C}$ treatments, respectively. This trend was maintained with increasing duration of the treatments, with the $12^{\circ} \mathrm{C}$ treatment showing the greatest decrease in $F_{\mathrm{v}} / F_{\mathrm{m}}$ throughout, followed by the $16^{\circ} \mathrm{C}$ treatment. While $F_{\mathrm{v}} / F_{\mathrm{m}}$ in the $20^{\circ} \mathrm{C}$ treatment was lower than the control treatment, this difference was not significant $(p>0.05)$. However, both the 16 and $12^{\circ} \mathrm{C}$ treatments were significantly different from the controls after 3 and $6 \mathrm{~h}$ exposure to colder temperatures ( $p<0.05$ and $<0.001$, respectively). Only the $12^{\circ} \mathrm{C}$ treatment was significantly different after 12 and $18 \mathrm{~h}$ exposure (Fig. 1).

There were no significant differences in $F_{0}$ between different temperature regimes throughout the experiment $(p>0.05)$. There was also no significant difference in $F_{0}$ between treatments at the 1, 3 and $6 \mathrm{~h}$ sampling times. However, after 12 and $18 \mathrm{~h}$ exposure, $F_{0}$ in the $16^{\circ} \mathrm{C}$ treatment increased substantially, although not significantly $(\mathrm{p}>0.05)$ compared to the 12 and $23^{\circ} \mathrm{C}$ treatments. The $F_{0}$ of the $20^{\circ} \mathrm{C}$ treatment also increased after $12 \mathrm{~h}$ (Fig. 2).

In comparison, $F_{\mathrm{m}}$ showed a significant reduction in both the 12 and $16^{\circ} \mathrm{C}$ treatments after $6 \mathrm{~h}$ exposure compared to the control $(p<0.01$ and $<0.01$, respectively). In the $12^{\circ} \mathrm{C}$ treatment, $F_{\mathrm{m}}$ remained significantly reduced throughout the experimental period
(12 h, p < 0.01; $18 \mathrm{~h}, \mathrm{p}<0.05)$. However in the $16^{\circ} \mathrm{C}$ treatment, $F_{\mathrm{m}}$ increased significantly after 12 and $18 \mathrm{~h}$ to the levels shown in the 20 and $23^{\circ} \mathrm{C}$ treatments, with a significant difference from the $12^{\circ} \mathrm{C}$ treatments observed $(\mathrm{p}<0.01)$ (Fig. 2).

Recovery of the photosynthetic efficiency of the dinoflagellates of corals (measured using $F_{\mathrm{v}} / F_{\mathrm{m}}$ ) also varied depending on treatment temperature and duration of exposure. In the control corals, $F_{\mathrm{v}} / F_{\mathrm{m}}$ remained consistent throughout the $4 \mathrm{~d}$ experiment, and was similar to levels measured in corals freshly collected from the field (range 0.56 to $0.62, \mathrm{n}=20$ ). Diurnal fluctuations in $F_{\mathrm{v}} / F_{\mathrm{m}}$ were apparent in the controls, with $F_{\mathrm{v}} / F_{\mathrm{m}}$ lowest after $6 \mathrm{~h}$ (corresponding to $14: 00 \mathrm{~h}$ ) and highest after $18 \mathrm{~h}$ (corresponding to $02: 00 \mathrm{~h}$ ). In the $20^{\circ} \mathrm{C}$ treatment, $F_{\mathrm{v}} / F_{\mathrm{m}}$ decreased slightly after 3,6 and $12 \mathrm{~h}$ exposure; however, there was no apparent decrease after 1 or $18 \mathrm{~h}$ exposure. $F_{\mathrm{v}} / F_{\mathrm{m}}$ then recovered over the next $72 \mathrm{~h}$. A similar trend was observed in the $16^{\circ} \mathrm{C}$ treatment, with an initial decrease in $F_{\mathrm{v}} / F_{\mathrm{m}}$, followed by recovery. In the $12^{\circ} \mathrm{C}$ treatment, $F_{\mathrm{v}} / F_{\mathrm{m}}$ showed the greatest initial decrease after $3,6,12$ and $18 \mathrm{~h}$ exposure. While $F_{\mathrm{v}} / F_{\mathrm{m}}$ did

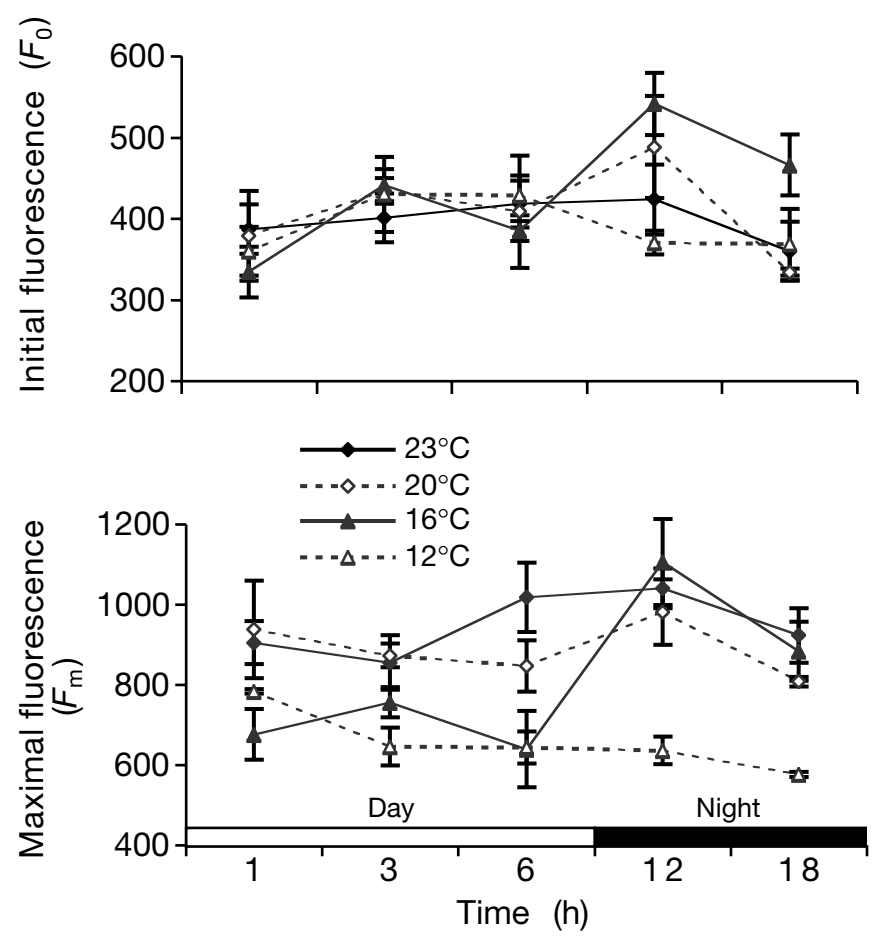

Fig. 2. Montipora digitata. Differences in initial fluorescence $\left(F_{0}\right)$ and maximal fluorescence $\left(F_{\mathrm{m}}\right)$ of the coral Montipora digitata immediately following exposure to 1 of 4 temperature treatments (23 [ambient], 20,16 or $12^{\circ} \mathrm{C}$ ) of varying duration $(1,3,6,12$ or $18 \mathrm{~h})$. The bar represents the day/night cycle 


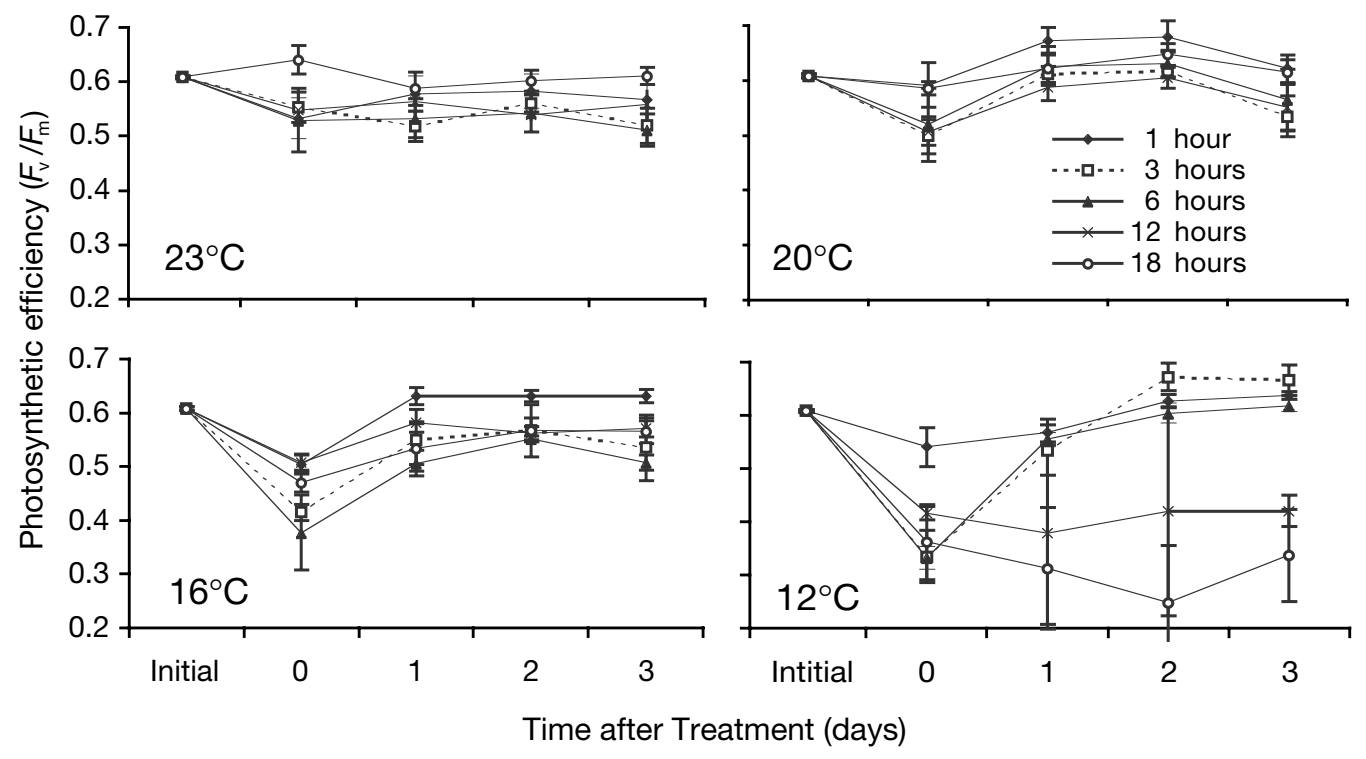

Fig. 3. Montipora digitata. Recovery of photosynthetic efficiency $\left(F_{\mathrm{v}} / F_{\mathrm{m}}\right)$ of the coral Montipora digitata over a $4 \mathrm{~d}$ period following exposure to 1 of 4 temperature treatments $\left(23\right.$ [ambient], 20, 16 or $12^{\circ} \mathrm{C}$ ) of varying duration $(1,3,6,12$ or $18 \mathrm{~h})$

recover in the 3 and $6 \mathrm{~h}$ treatments, there was no recovery of $F_{\mathrm{v}} / F_{\mathrm{m}}$ after 12 or $18 \mathrm{~h}$ exposure at $12^{\circ} \mathrm{C}$. This lack of recovery corresponded to severe coral bleaching and/or resulting mortality. It must be noted that recovery was not complete in either the 12 or the $16^{\circ} \mathrm{C}$ treatment, as $F_{\mathrm{v}} / F_{\mathrm{m}}$ remained considerably depressed when compared to initial levels (Fig. 3).

Concentration of photosynthetic pigments and symbiotic dinoflagellates

The duration of exposure to decreased temperature showed no significant effect $(p>0.05)$ on either the concentration of photosynthetic pigments or the density of symbiotic dinoflagellates. Therefore, results were pooled to give an indication of overall trends of these parameters between the 4 different temperature treatments. The $12^{\circ} \mathrm{C}$ treatment showed a significant decrease in chl $a, C$, and $a+c$ content compared to the other treatments $(\mathrm{p}<0.001)$. The $12^{\circ} \mathrm{C}$ treatment also showed a significant decrease in the density of symbiotic dinoflagellates from the 23 and $20^{\circ} \mathrm{C}$ treatments $(p<0.001)$. There were no significant differences in the chl a:c ratio or in phaeophytin content between treatments ( $p>0.05)$. However, the $16^{\circ} \mathrm{C}$ treatment showed a significant increase from the $23^{\circ} \mathrm{C}$ control in chl a $\mathrm{cm}^{-2}$ and $\mathrm{chl} a+c$ content, and in chl a content per dinoflagellate $(\mathrm{p}<0.01,<0.05$ and $<0.001$, respectively). Chl a content per dinoflagellate was also significantly increased in the $16^{\circ} \mathrm{C}$ treatment compared to the $12^{\circ} \mathrm{C}$ treatment $(\mathrm{p}<0.001)$ (Table 1$)$.

\section{Synergistic effects of light and temperature}

\section{Photosynthetic efficiency}

There were significant differences in photochemical efficiency $\left(F_{\mathrm{v}} / F_{\mathrm{m}}\right)$ dependent upon the combination of the temperature and light regime. Photochemical efficiency of dinoflagellates within the corals exposed to $14^{\circ} \mathrm{C}$ under $100 \%$ incident irradiance was significantly decreased (0.46) compared to corals exposed to $20^{\circ} \mathrm{C}$ $(0.53)$ and $26^{\circ} \mathrm{C}(0.58)(\mathrm{p}<0.001)$. The $14^{\circ} \mathrm{C}$ treatment was also significantly lower $(0.53)$ than the $26^{\circ} \mathrm{C}$ treatment $(0.60)$ at $50 \%$ light $(p<0.01)$. However, there were no significant differences between any of the 3 temperature treatments at $0 \%$ light ( $\mathrm{p}>0.05)$.

Following exposure to $14^{\circ} \mathrm{C}$, photochemical efficiency was also significantly different between the $100 \%$ light treatment and corals maintained at 0 and $50 \%$ light $(\mathrm{p}<0.05$ and $<0.001$, respectively). While photochemical efficiency decreased at higher light intensities in the $20^{\circ} \mathrm{C}$ treatment, these differences were not significantly different $(p>0.05)$ either within the treatment or when compared to the control (Fig. 4).

The reductions in photochemical efficiency can be explained by changes in the $F_{0}$ and $F_{\mathrm{m}}$ of the corals. At $100 \%$ light, both the 14 and $20^{\circ} \mathrm{C}$ treatments showed a significant increase in $F_{0}$ from the control at all light levels ( $\mathrm{p}<0.001$ and $<0.01$, respectively). At $50 \%$ light, the $14^{\circ} \mathrm{C}$ treatment is also significantly higher than the control $(\mathrm{p}<0.01)$. Overall, there is an increase in $F_{0}$ with decreasing temperature. $F_{\mathrm{m}}$ also varies significantly between different treatments and light 
Table 1. Montipora digitata. Differences in chl a and chl c parameters and the density of dinoflagellates in the coral Montipora digitata following exposure to 1 of 4 temperature treatments $\left(23\right.$ [ambient], 20, 16 or $\left.12^{\circ} \mathrm{C}\right) .{ }^{*} \mathrm{p}<0.05,{ }^{* *} \mathrm{p}<0.01,{ }^{* * *} \mathrm{p}<0.001$. ${ }^{\mathrm{abc}}$ Means with different letters are significantly different at $\mathrm{p}<0.05$

\begin{tabular}{|c|c|c|c|c|c|c|c|}
\hline $\begin{array}{l}\text { Temp. } \\
\left({ }^{\circ} \mathrm{C}\right)\end{array}$ & $\begin{array}{l}\text { Chl a content } \\
\left(\mu \mathrm{g} \mathrm{cm}^{-2}\right)\end{array}$ & $\begin{array}{l}\text { Chl } c \text { content } \\
\left(\mu \mathrm{g} \mathrm{cm}^{-2}\right)\end{array}$ & $\begin{array}{c}\text { Chl a: } c \\
\text { ratio }\end{array}$ & Chl $a+c$ & $\begin{array}{c}\text { Phaeophytin } \\
\text { content } \\
\left(\mu \mathrm{g} \mathrm{cm}^{-2}\right)\end{array}$ & $\begin{array}{c}\text { Dinoflagellate } \\
\text { density } \times 10^{6} \\
\left(\mathrm{~cm}^{-2}\right)\end{array}$ & $\begin{array}{c}\text { Chl a per } \\
\text { dinoflagellate } \\
\left(\text { pg cell }{ }^{-1}\right)\end{array}$ \\
\hline 23 & $3.55^{\mathrm{a}}$ & $2.65^{\mathrm{a}}$ & 1.37 & $6.20^{\mathrm{a}}$ & 0.27 & $3.51^{\mathrm{a}}$ & $1.08^{\mathrm{a}}$ \\
\hline 20 & $4.19^{\mathrm{ab}}$ & $2.87^{\mathrm{a}}$ & 1.55 & $7.06^{\mathrm{ab}}$ & 0.32 & $3.64^{\mathrm{a}}$ & $1.17^{\mathrm{a}}$ \\
\hline 16 & $4.71^{\mathrm{b}}$ & $3.01^{\mathrm{a}}$ & 1.64 & $7.72^{\mathrm{b}}$ & 0.25 & $3.04^{\mathrm{ab}}$ & $1.63^{b}$ \\
\hline 12 & $2.09^{c}$ & $1.49^{\mathrm{b}}$ & 1.60 & $3.58^{\mathrm{c}}$ & 0.20 & $2.37^{\mathrm{b}}$ & $0.93^{\mathrm{a}}$ \\
\hline$F$-value & $21.6^{* * *}$ & $18.5^{* * *}$ & 1.1 & $24.8^{* * *}$ & 0.2 & $9.4^{* * *}$ & $12.4^{* * *}$ \\
\hline
\end{tabular}

regimes. In the $14^{\circ} \mathrm{C}$ treatment, $F_{\mathrm{m}}$ is significantly reduced at $100 \%$ light compared to at $50 \%(\mathrm{p}<0.01)$. At $0 \%$ light, $F_{\mathrm{m}}$ in the $26^{\circ} \mathrm{C}$ control is significantly lower than in the 14 and $20^{\circ} \mathrm{C}$ treatments $(\mathrm{p}<0.001$ and $<0.05$, respectively). Overall, there is an increase in $F_{\mathrm{m}}$ with decreasing temperature in both the 50 and $0 \%$ light treatments; however, in the $100 \%$ light treatment $F_{\mathrm{m}}$ decreases again in the $14^{\circ} \mathrm{C}$ treatment (Fig. 5).

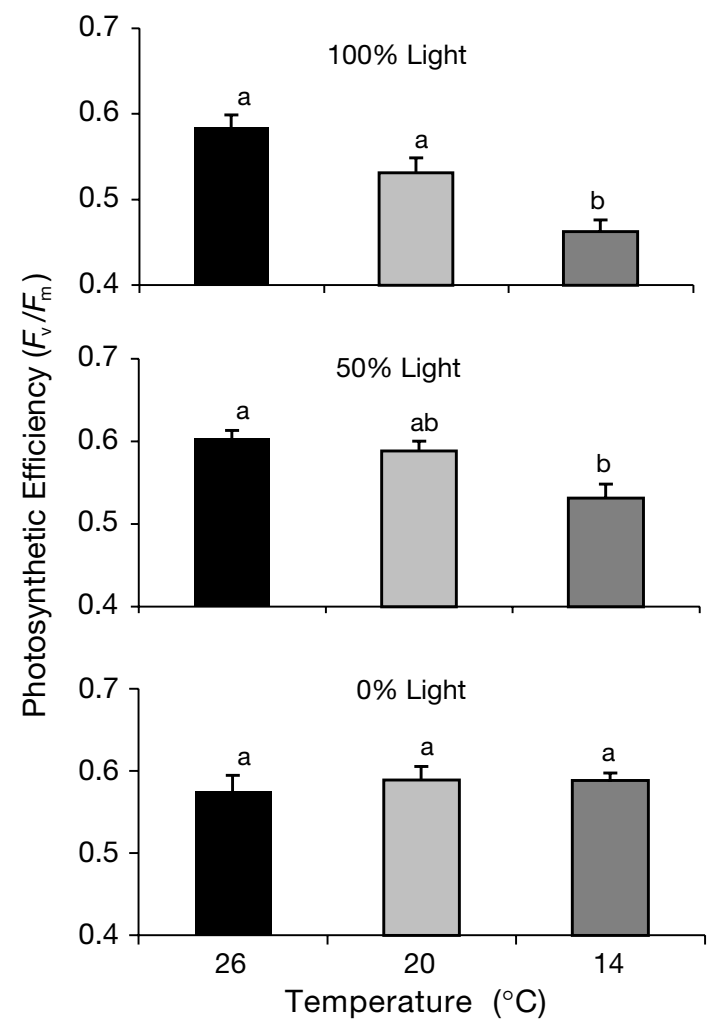

Fig. 4. Montipora digitata. Photosynthetic efficiency $\left(F_{\mathrm{v}} / F_{\mathrm{m}}\right)$ of the coral Montipora digitata following exposure to different temperature treatments $\left(14,20\right.$ or $\left.26^{\circ} \mathrm{C}\right)$ and light regimes $(0$, 50 or $100 \%$ ). ${ }^{\text {abc }}$ Means with different letters are significantly different at $\mathrm{p}<0.05$

\section{Density of symbiotic dinoflagellates}

The density of symbiotic dinoflagellates was significantly reduced in the $14^{\circ} \mathrm{C}$ treatment compared to the $20^{\circ} \mathrm{C}$ treatment in all light regimes $(\mathrm{p}<0.01)$. There was also a significant difference between the $26^{\circ} \mathrm{C}$ treatment and the $14^{\circ} \mathrm{C}$ treatment at $100 \%(\mathrm{p}<0.05)$ (Fig. 6).

$\mathrm{Chl}$ a content per symbiotic dinoflagellate showed significant increases in the $14^{\circ} \mathrm{C}$ treatment at 50 and $100 \%$ light, compared to the control treatment $(\mathrm{p}<$ 0.001 and < 0.001, respectively). Generally, chl a content per dinoflagellate appeared to increase with decreasing temperature at all light levels (Fig. 7).

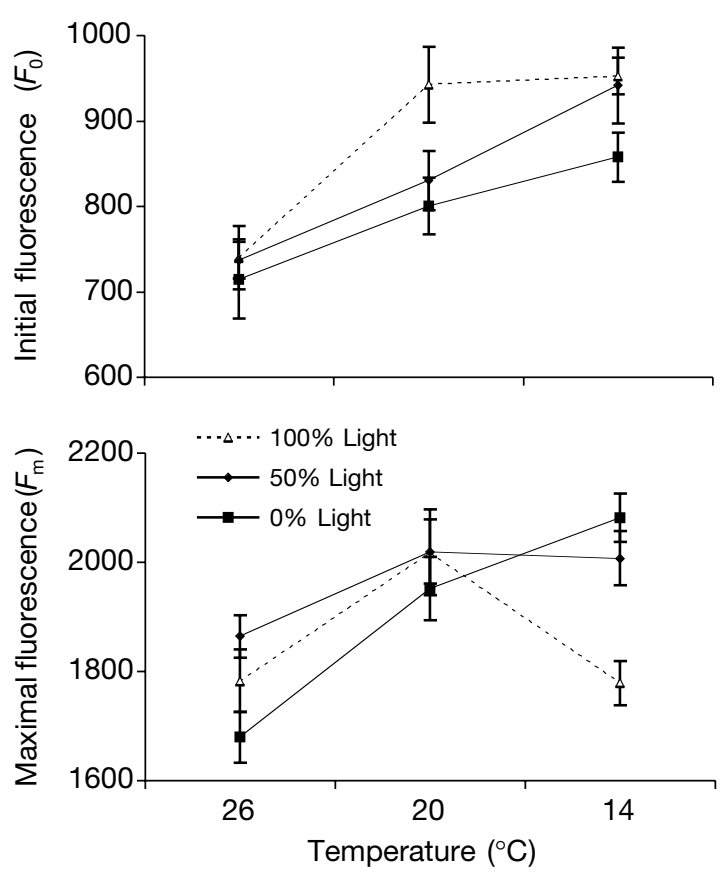

Fig. 5. Montipora digitata. Differences in initial fluorescence $\left(F_{0}\right)$ and maximal fluorescence $\left(F_{\mathrm{m}}\right)$ of the coral Montipora digitata immediately following exposure to 1 of 3 temperature treatments (26 [ambient], 20 or $14^{\circ} \mathrm{C}$ ), while maintained under 1 of 3 light regimes $(100,50$ or $0 \%)$ 


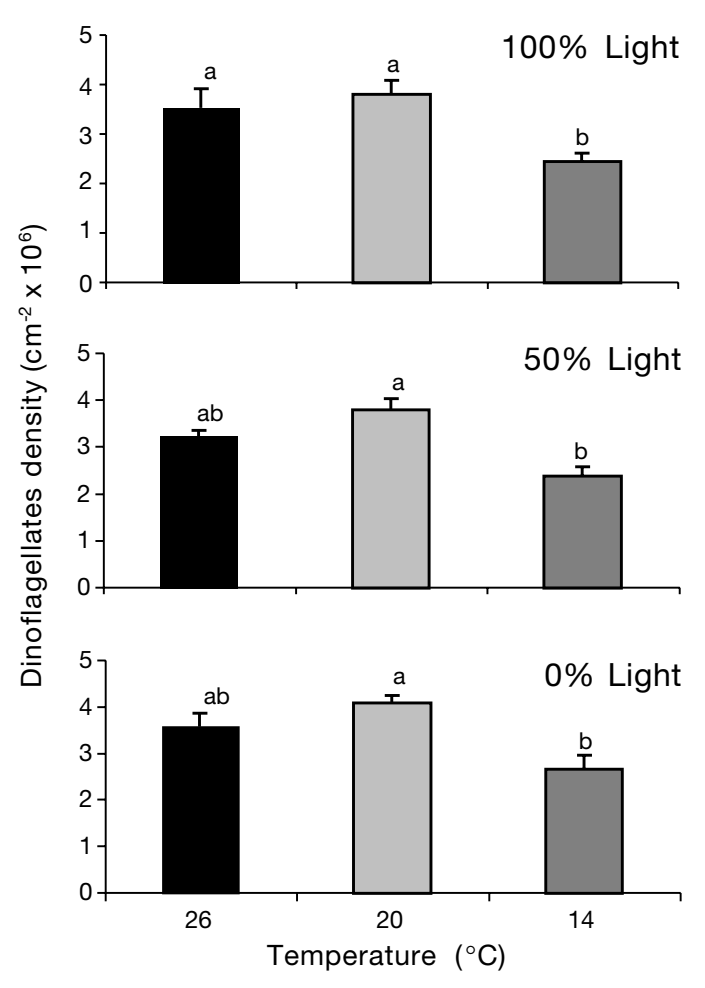

Fig. 6. Montipora digitata. Density of symbiotic dinoflagellates $\mathrm{cm}^{-2}$ of the coral Montipora digitata following exposure to 1 of 3 different temperature treatments $\left(14,20\right.$ or $\left.26^{\circ} \mathrm{C}\right)$, while maintained at 1 of 3 light regimes $(100,50$ or $0 \%)$. ${ }^{a b c}$ Means with different letters are significantly different at

$$
\mathrm{p}<0.05
$$

\section{Concentration of photosynthetic pigments}

In the $100 \%$ light regime, chl a content increased slightly in the $14^{\circ} \mathrm{C}$ treatment when compared to the $26^{\circ} \mathrm{C}$ ambient control. Under 50 and $0 \%$ light, this trend was more pronounced, with a significant difference observed between the $20^{\circ} \mathrm{C}$ treatment and the $26^{\circ} \mathrm{C}$ treatment at 0 and $50 \%$ light $(\mathrm{p}<0.05$ and $<0.01$, respectively) (Table 2).

There was a significant increase in chl $C$ content in the $20^{\circ} \mathrm{C}$ treatment compared to the $14^{\circ} \mathrm{C}$ and $26^{\circ} \mathrm{C}$ treatments under all light regimes ( $p<0.001$ and $<0.001$, respectively). This increase corresponded with a large decrease in the $\mathrm{chl}$ a:c ratio in the $20^{\circ} \mathrm{C}$ treatment under all light regimes, as the amount of $\mathrm{chl} C$ increased relative to $\mathrm{chl} a$. The ratio of chl a: $c$ appeared to increase with increasing light in the 14 and $26^{\circ} \mathrm{C}$ treatments, indicating a relative de-

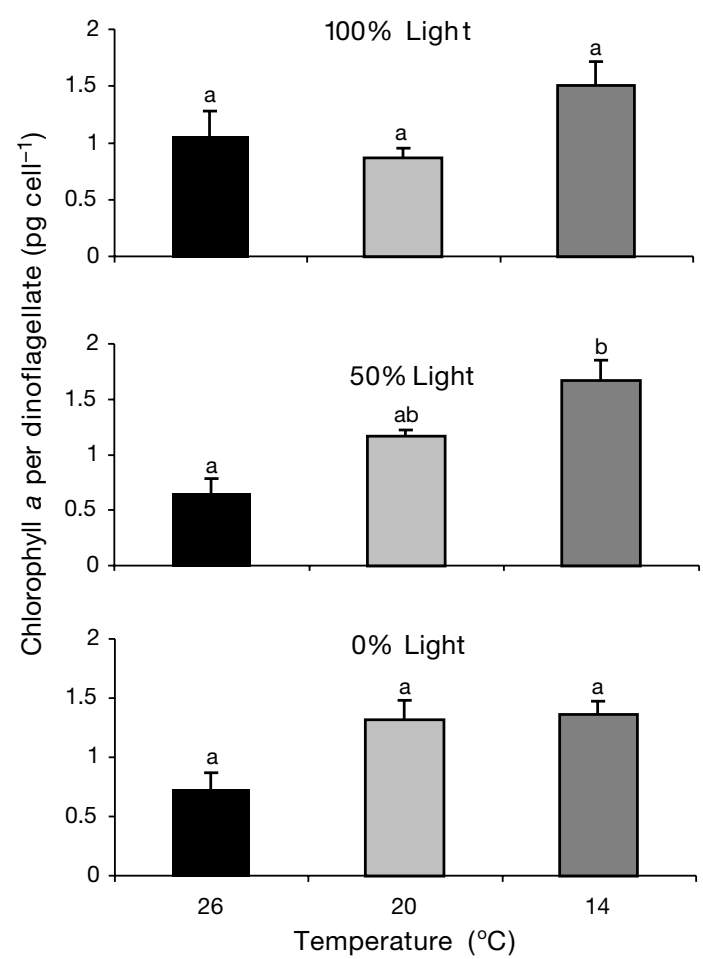

Fig. 7. Montipora digitata. Differences in chl a content per symbiotic dinoflagellates in the coral Montipora digitata following exposure to 1 of 3 different temperature treatments $\left(14,20\right.$ or $\left.26^{\circ} \mathrm{C}\right)$, while maintained under 1 of 3 light regimes $(100,50$ or $0 \%)$. ${ }^{\text {abc }}$ Means with different letters are significantly different at $\mathrm{p}<0.05$

crease in chl $c$ content. The overall content of photosynthetic pigments $(\mathrm{chl} a+c)$ showed a significant increase in the $20^{\circ} \mathrm{C}$ treatment at 50 and $0 \%$ light compared to the 14 and $26^{\circ} \mathrm{C}$ treatments $(\mathrm{p}<0.001$ and

Table 2. Montipora digitata. Differences in chl a and chl $c$ parameters in the symbiotic dinoflagellates of the coral Montipora digitata following treatment at 1 of 3 temperatures (26 [ambient], 20 and $14^{\circ} \mathrm{C}$ ) and 3 light regimes $(100,50$ and $0 \%$ ). ${ }^{*} \mathrm{p}<0.05,{ }^{* *} \mathrm{p}<0.01,{ }^{* * *} \mathrm{p}<0.001 .{ }^{\text {abc }}$ Means with different letters are significantly different at $p<0.05$

\begin{tabular}{|c|c|c|c|c|c|c|}
\hline $\begin{array}{l}\text { Temp. } \\
\left({ }^{\circ} \mathrm{C}\right)\end{array}$ & $\begin{array}{c}\text { Light } \\
\text { intensity } \\
(\%)\end{array}$ & $\begin{array}{c}\text { Chl a } \\
\left(\mu \mathrm{g} \mathrm{cm}^{-2}\right)\end{array}$ & $\begin{array}{c}\mathrm{Chl} \mathrm{C} \\
\left(\mu \mathrm{g} \mathrm{cm}^{-2}\right)\end{array}$ & $\begin{array}{c}\text { Chl a:C } \\
\text { ratio }\end{array}$ & $\begin{array}{l}\text { Chl } a+C \\
\left(\mu \mathrm{g} \mathrm{cm}^{-2}\right)\end{array}$ & $\begin{array}{c}\text { Phaeo- } \\
\text { phytin } \\
\left(\mu \mathrm{cm}^{-2}\right)\end{array}$ \\
\hline 26 & $\begin{array}{r}100 \\
50 \\
0\end{array}$ & $\begin{array}{l}3.60^{\mathrm{ab}} \\
2.09^{\mathrm{a}} \\
2.48^{\mathrm{a}}\end{array}$ & $\begin{array}{l}2.56^{\mathrm{a}} \\
2.78^{\mathrm{a}} \\
2.38^{\mathrm{a}}\end{array}$ & $\begin{array}{l}4.15^{\mathrm{a}} \\
0.93^{\mathrm{a}} \\
1.15^{\mathrm{a}}\end{array}$ & $\begin{array}{l}6.16^{\mathrm{ab}} \\
4.39^{\mathrm{a}} \\
4.87^{\mathrm{a}}\end{array}$ & $\begin{array}{l}0.35^{\mathrm{a}} \\
0.28^{\mathrm{a}} \\
0.43^{\mathrm{a}}\end{array}$ \\
\hline 20 & $\begin{array}{r}100 \\
50 \\
0\end{array}$ & $\begin{array}{l}3.23^{\mathrm{ab}} \\
4.41^{\mathrm{b}} \\
5.32^{\mathrm{b}}\end{array}$ & $\begin{array}{l}4.71^{\mathrm{b}} \\
4.70^{\mathrm{b}} \\
4.85^{\mathrm{b}}\end{array}$ & $\begin{array}{l}0.71^{\mathrm{a}} \\
0.94^{\mathrm{a}} \\
1.07^{\mathrm{a}}\end{array}$ & $\begin{array}{c}7.95^{\mathrm{ab}} \\
9.11^{\mathrm{b}} \\
10.17^{\mathrm{b}}\end{array}$ & $\begin{array}{l}0.03^{\mathrm{b}} \\
0.10^{\mathrm{b}} \\
0.13^{\mathrm{b}}\end{array}$ \\
\hline 14 & $\begin{array}{r}100 \\
50 \\
0\end{array}$ & $\begin{array}{l}3.83^{\mathrm{ab}} \\
3.75^{\mathrm{ab}} \\
3.51^{\mathrm{ab}}\end{array}$ & $\begin{array}{l}1.75^{\mathrm{a}} \\
2.01^{\mathrm{a}} \\
2.47^{\mathrm{a}}\end{array}$ & $\begin{array}{l}2.11^{\mathrm{a}} \\
1.92^{\mathrm{a}} \\
1.46^{\mathrm{a}}\end{array}$ & $\begin{array}{l}5.59^{\mathrm{ab}} \\
5.75^{\mathrm{a}} \\
5.97^{\mathrm{a}}\end{array}$ & $\begin{array}{l}0.63^{\mathrm{a}} \\
0.47^{\mathrm{a}} \\
0.72^{\mathrm{a}}\end{array}$ \\
\hline$F$-values & & $9.5^{* * *}$ & $62.8^{* * *}$ & 1.1 & $26.7^{* * *}$ & $48.3^{* *}$ \\
\hline
\end{tabular}


$<0.001$, respectively). This increase in chl $a+c$ content contrasts with the amount of phaeophytin present, with a significant decrease observed in the $20^{\circ} \mathrm{C}$ treatment compared to the 14 and $26^{\circ} \mathrm{C}$ treatments $(\mathrm{p}<0.01$ and < 0.05) (Table 2).

\section{DISCUSSION}

The impact of changes to sea temperature has been a major issue in recent literature due to the widespread impacts of mass coral bleaching events (Glynn 1993, Hoegh-Guldberg 1999) and the global importance of climate change. Most previous studies have focused on the effects of increased sea surface water temperatures. While average temperatures are increasing in tropical areas due to greenhouse warming (IPCC 2000), the influence of climate change on the overall variability of weather systems, like the ENSO, suggest that there may be periods in which colder than normal temperatures (during La Niña phase conditions) may be experienced. There is little knowledge or understanding of how these colder excursions in sea temperature (e.g. during La Niña periods) will affect marine organisms. This study has explored how reduced temperatures will impact a coral-dinoflagellate symbiosis (Montipora digitata).

\section{Synergistic effects of light and temperature}

The results of the present study clearly show that exposure to cold water stress has a negative impact on the physiology of the coral Montipora digitata. This was indicated by decreased photosynthetic efficiency, loss of symbiotic dinoflagellates, and changes in concentrations of photosynthetic pigments associated with chl degradation. Experimental results suggest that the mechanisms of coral bleaching at lowered temperatures are similar to those involved in elevated temperature stress. It is well documented that decreased temperatures intensify photoinhibition in higher plants (Lyons 1973, Smillie et al. 1988, Aro et al. 1990, Greer 1990, Greer \& Laing 1991, Foyer et al. 1994, Long et al. 1994) due to a reduction in the rate at which the quenching of PSII develops (Krause 1992). In the present study, decreased temperatures clearly exacerbated the photoinhibitory response of corals at higher light intensities and produced physiological responses similar to those observed in corals exposed to elevated temperatures (Jones et al. 1998).

Symbiotic corals exposed to cold water conditions and high light intensity had significant decreases in photochemical efficiency $\left(F_{\mathrm{v}} / F_{\mathrm{m}}\right)$ and reduced numbers of viable dinoflagellates compared to the controls.
Decreased photochemical efficiency is indicative of photoinhibition (Schreiber \& Bilger 1987, HoeghGuldberg \& Jones 1999), while reduced dinoflagellate density is a response that is typical of general stress among reef-building corals. These responses implicate an increased sensitivity to photoinhibition as a key aspect associated with coral bleaching following exposure of corals to cold water stress. Previous studies have also shown increased respiration of the symbiotic dinoflagellates in response to lowered temperatures (Steen \& Muscatine 1987), probably due to the direct effects of lower temperature on the activity of enzymes and their substrates.

\section{Mechanisms of low and high thermal stress}

One model for explaining the increased susceptibility of corals to photoinhibition with decreasing temperatures is that it is also due to the impairment of the Calvin-Benson cycle as suggested for dinoflagellates experiencing elevated temperature stress (Jones et al. 1998, Hoegh-Guldberg 1999). Given that rates of enzyme activity are temperature dependent (with a $Q_{10}$ of around 2; Nobel 1991), decreasing temperature is likely to reduce the rate at which the enzymes catalyzing the Calvin-Benson cycle operate. Given that the $Q_{10}$ of light reactions is much less than 2 (Nobel 1991), the subsequent reduction in photosynthetic electron transport combined with continued high absorption of light energy leads to a reduced capacity to process excitations and hence, over-reduction of the light reactions. This, in turn, leads to damage or inactivation of photosynthetic components (including PSII) as a result of the production of toxic oxygen species (Osmond 1994, Lesser 1996). The photosystem has a decreased capacity to capture and process photons (Long et al. 1994, Osmond 1994), characterized by the accumulation of photochemically inactive PSII reaction centers (Krause 1994). This typically results in a decrease in the overall photosynthetic rate (Richter et al. 1990), indicated by increased baseline fluorescence $\left(F_{0}\right)$, which translates as a decreased yield $\left(F_{\mathrm{v}} / F_{\mathrm{m}}\right)$; a phenomena also observed in the present study.

The resulting cellular damage to the symbiotic dinoflagellates caused by oxidative stress results in an energetic cost to the coral host, either in terms of decreased translocation of photosynthate or exposure to highly reactive oxygen radicals (Lesser \& Shick 1989). As a result, the dinoflagellates are expelled from the host tissues, probably as a protective mechanism against further oxidative stress (Lesser 1997). This was supported by the present study as the density of symbiotic dinoflagellates was significantly reduced with decreasing temperatures and increasing light (Fig. 8). 


\section{AMBIENT TEMPERATURES}

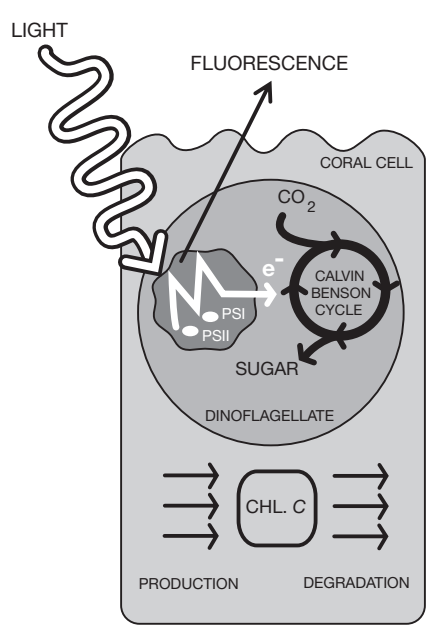

\section{MODERATE COLD STRESS}

\section{LIGHT}

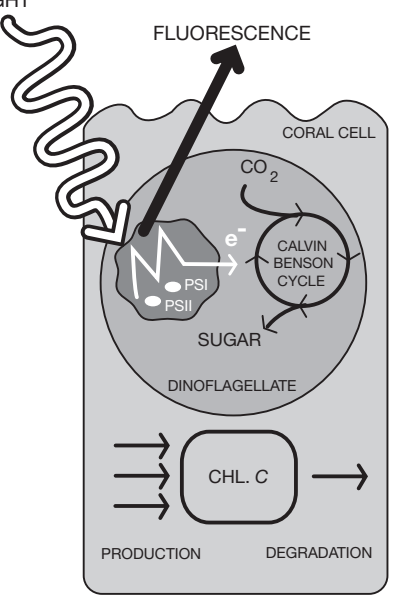

\section{SEVERE COLD STRESS}

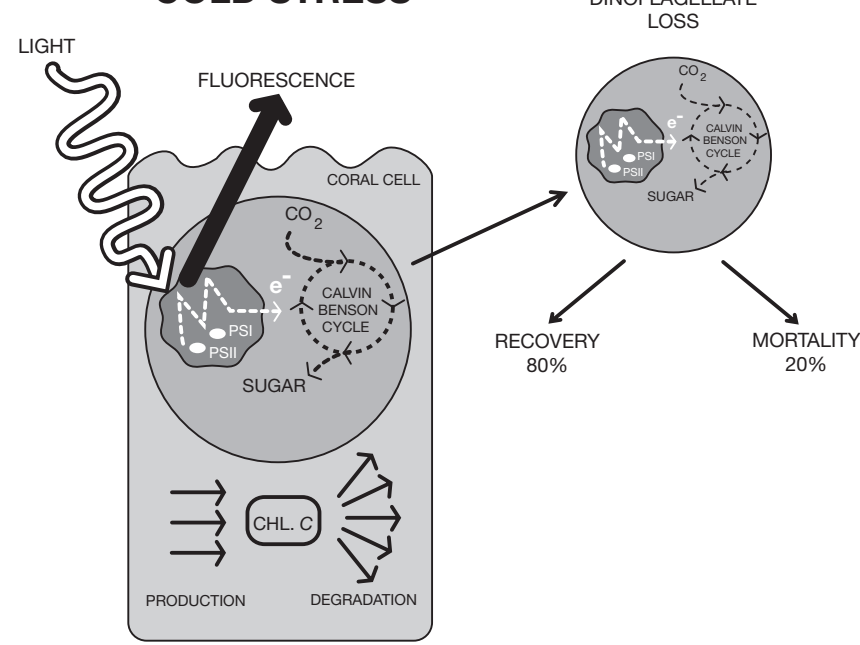

Fig. 8. Montipora digitata. Conceptual model showing the effects of light and cold water stress on the physiological reactions of symbiotic dinoflagellates in the coral M. digitata

\section{Variation in biomass parameters}

Chl a content per symbiotic dinoflagellate showed a significant increase in corals subjected to $14^{\circ} \mathrm{C}$ at 50 and $100 \%$ light compared to controls. Increases in the content of chl a present in the endosymbiotic dinoflagellates have previously been recorded following stress-related loss of symbiotic dinoflagellates due to sub-aerial exposure (Le Tissier \& Brown 1996) and heat induced bleaching (Jones 1997, Brown et al. 2000). This is in contrast to several different studies that have reported decreased concentrations of photosynthetic pigments per dinoflagellate in bleached corals (Hoegh-Guldberg \& Smith 1989a, Kleppel et al. 1989, Porter et al. 1989, Jokiel \& Coles 1990, Shing et al. 1995). There are 4 possible causes for this increase in both overall chl a content and chl a content per dinoflagellate: (1) confounding effects of chl breakdown products; (2) a mechanism of dinoflagellate loss; (3) nutrient status of the dinoflagellates; and (4) effect on enzymatic reactions.

Previous work has indicated that increased chl a could be an artifact of chl breakdown products, such as phaeophytin and pyrophaeophytin, following symbiotic dinoflagellate loss (Jones 1997), which has been observed in considerable quantities in bleached tissues of Goniastrea aspera (Ambarsari et al. 1997). While there were significantly higher concentrations of phaeophytins detected in the tissues of the corals subjected to the $14^{\circ} \mathrm{C}$ treatment, chl a content has been corrected for these.

It is possible that these observed differences in both chl $a$ and phaeophytin content are related to the mech- anism of symbiotic dinoflagellate expulsion. For example, in Goniastrea aspera, the mechanism of dinoflagellate loss possibly involved in situ degradation, where the algal cell degrades inside the host coral tissue before being expelled (Brown 1997a). This would explain the increased concentrations of both phaeophytin and pyrophaeophytin within the coral tissues.

Alternatively, the observed increase in chl a content could be related to the nutrient status of the algal symbionts (Hoegh-Guldberg \& Smith 1989b, Jones 1997). Chl a concentration of endosymbiotic dinoflagellates has been proven to be a reliable indicator of nutrient status (Hoegh-Guldberg \& Smith 1989b, Rees 1991), with increased chl a production observed in corals exposed to increased levels of nutrients (Hoegh-Guldberg \& Smith 1989b). Nutrient enrichment also increases the cell-specific density of symbiotic dinoflagellates, as well as increasing division rates (Muscatine et al. 1998). Increased division frequencies of dinoflagellates also occur in bleached but recovering corals (Fitt et al. 1993, Hoegh-Guldberg \& Smith 1989b, Jones \& Yellowlees 1997). It is therefore likely that the loss of the symbiotic dinoflagellates from the tissues of affected corals triggers increases in production of chl a and increased algal cell division in response to increased availability of nutrients, either from the degradation of damaged algal cells or from decreased competition for limiting nutrients such as nitrogen and iron (Hoegh-Guldberg \& Smith 1989b, Ferrier-Pages et al. 2001).

Finally, the significant increase in both chls $a$ and $C$ content in the $20^{\circ} \mathrm{C}$ treatment compared to the 14 and $26^{\circ} \mathrm{C}$ treatments at all light regimes could be explained 
by the effect of temperature on enzymatic reactions. While the Calvin-Benson cycle may be slowed in the $20^{\circ} \mathrm{C}$ treatment due to a temperature-related decrease in enzyme activity (Hoegh-Guldberg 1995), there was no apparent damage to PSII. This lack of damage is possibly due to a down-regulation of photosynthesis associated with chl fluorescence quenching (Bruce et al. 1997, Brown et al. 1999). This photoprotective mechanism is known as non-photochemical quenching, which functions by dissipating excess absorbed light energy in the PSII antenna system as heat (Demmig-Adams 1990). Therefore, to cope with the excess light energy caused by lowered efficiency of the Calvin-Benson cycle, more chl $c$ is produced to act as a quenching mechanism. This was substantiated by the reduction in chls $a$ and $c$ turnover (indicated by decreased phaeophytins), and the relative decrease in the chl a:c ratio with increasing light in the $20^{\circ} \mathrm{C}$ treatment, and compared to the 14 and $26^{\circ} \mathrm{C}$ treatments, indicating higher relative chl $c$ content (Plate 1). A similar response to lowered temperatures was also observed in corals exposed to a $16^{\circ} \mathrm{C}$ treatment, with significantly increased concentrations of chls $a$ and $a+c$ compared to the ambient control.

\section{Effect of duration of temperature stress}

Previous experiments have shown that many coral species can only tolerate low temperatures for short periods, specifically $15^{\circ} \mathrm{C}$ (Roberts et al. 1982), and that the massive coral Montastrea annularis cannot survive water temperatures of $14^{\circ} \mathrm{C}$ for more than $9 \mathrm{~h}$ (Mayer 1914). However, specific species of corals (e.g. Plesiastrea versipora; Kevin \& Hudson 1979) can survive temperatures as low as $11.5^{\circ} \mathrm{C}$ for several months (Coles \& Fadlallah 1991). In the present study, the duration of the applied cold treatment had a major effect on the photochemical efficiency of the dinoflagellates within treated corals. The observed decrease in the ratio of variable fluorescence to maximal fluorescence was primarily related to a decrease in $F_{\mathrm{m}}$ following exposure to decreased temperatures, indicating increased photoprotection (Jones \& Hoegh-Guldberg 2001). It appears that a similar set of physiological phenomena to heat stress occur as dinoflagellates and their coral hosts are exposed to cold stress.

Differences in $F_{\mathrm{m}}$ and hence, $F_{\mathrm{v}} / F_{\mathrm{m}}$ of corals within the control and treatment groups, may be due to diurnal fluctuations in photochemical efficiency. Previous studies have shown that marine dinoflagellates have clear diurnal cycles of photochemical efficiency, with $F_{\mathrm{v}} / F_{\mathrm{m}}$ decreasing after dawn to reach a low between midday and early afternoon, then recovering during late afternoon and early evening (Brown et al. 1999,
Hoegh-Guldberg \& Jones 1999, Jones \& Hoegh-Guldberg 2001). This pattern is consistent with the substantial increase in $F_{\mathrm{v}} / F_{\mathrm{m}}$ in all treatment temperatures after the $6 \mathrm{~h}$ sampling time $(14: 00 \mathrm{~h})$. While temperature still has a significant effect on $F_{\mathrm{v}} / F_{\mathrm{m}}$, its impact is tempered by the natural diel cycle of the symbiotic dinoflagellates. Therefore, at the 12 and $18 \mathrm{~h}$ sampling times $\left(20: 00\right.$ and $02: 00 \mathrm{~h}$, respectively), $F_{\mathrm{v}} / F_{\mathrm{m}}$ recovered slightly due to the absence of light.

It is important to note that duration had no significant effect on either the density of symbiotic dinoflagellates or photosynthetic pigment concentration in any of the different temperature treatments. Therefore, while the duration of the exposure to cold water stress affected the short-term response of the corals to stress (i.e. photoprotection), the overall impact remained the same. This is similar to another study on the sea anemones Aiptasia pulchella and A. pallida, which showed that increasing duration of cold stress did not elicit further release of dinoflagellates after a certain threshold was reached (Muscatine et al. 1991). In contrast, time did play a major role in the ultimate survival of corals after exposure to cold stress, as mortality only occurred in those corals exposed to $12^{\circ} \mathrm{C}$ for more than $12 \mathrm{~h}$. This could be related to the effects of cold temperatures on host cells (Watson \& Morris 1987). Reduced temperature is known to increase membrane permeability and change the relative rates of reactions (via effects on the kinetic energy of enzymes and substrates), leading to metabolic disorder and greatly reduced rates of cell division (HoeghGuldberg 1995). It can therefore be suggested that cold water bleaching events are analogous to warm water bleaching events in that severe coral bleaching preceding mortality only occurs once the thermal and temporal limits of a particular coral are exceeded.

\section{Short-term recovery}

The partial recovery of photochemical efficiency of symbiotic dinoflagellates in cold stressed coral occurred over a $24 \mathrm{~h}$ period after corals were returned to ambient temperature. However, $F_{\mathrm{v}} / F_{\mathrm{m}}$ remained substantially lower than initial levels throughout the $3 \mathrm{~d}$ monitoring period. This pattern of short-term recovery has also been observed following exposure of corals to heat stress and cyanide (Jones \& HoeghGuldberg 1999, Jones et al. 2000). It has been suggested that this initial increase in $F_{\mathrm{v}} / F_{\mathrm{m}}$ occurs through the selective expulsion of damaged dinoflagellates (Jones et al. 2000), thereby increasing the relative proportion of unaffected algal cells. This is supported by the apparent bleaching that occurred throughout this period in both the 12 and $16^{\circ} \mathrm{C}$ treatments, substanti- 
ated by the significant loss of symbiotic dinoflagellates and decreased chls $a$ and $c$ content. However, while bleaching was greatest in the corals exposed to $12^{\circ} \mathrm{C}$ for 12 and $18 \mathrm{~h}$, no recovery of $F_{\mathrm{v}} / F_{\mathrm{m}}$ was observed following treatment. The lack of recovery in these cases is probably due to extreme cellular damage caused by irreversible photodamage, resulting in expulsion of damaged algal cells.

In addition to photo-oxidative stress induced by photoinhibition, lowered temperatures appear to have other deleterious physiological effects. In a study by Muscatine et al. (1991), the principal mechanism of expulsion of symbiotic dinoflagellates following cold stress involved the sloughing off of intact endodermal cells containing symbiotic dinoflagellates in various stages of degradation. This response was also observed in the present study following exposure of corals to $12^{\circ} \mathrm{C}$ for 12 and $18 \mathrm{~h}$ periods, but did not occur in corals treated for shorter periods of time. This suggests that there may be a correlation between the type of stress imposed upon the coral, as well as its severity and duration, and the mechanism of coral/algal dissociation. The mechanisms involved may also vary depending on whether the environmental stress principally affects the host cells (Gates et al. 1992) or the algal symbionts (Glynn \& D'Croz 1990, Lesser et al. 1990, Iglesias-Prieto et al. 1992).

\section{CONCLUSIONS}

The present study explored the impact of cold stress on a symbiotic coral species growing at the southern end of the Great Barrier Reef. Reducing the sea temperature to below that normally experienced by Montipora digitata led to the advent of physiological stress, both in its tissues and in the symbiotic dinoflagellates. Lowered temperatures increased the sensitivity of the endosymbiotic dinoflagellates of Montipora digitata to photoinhibition. The observed effects appeared to be similar to those observed in warm water bleaching of corals, indicated by loss of algal symbionts, and longterm reduction in photosynthetic efficiency (HoeghGuldberg 1999). These impacts have significance for projecting how coral communities are likely to change during climate warming. As climate warming occurs, the increased variability around climate systems like ENSO could have an independent and strong impact on reef-building coral communities during unusually cold periods like those seen in some parts of the world during strong La Niña phase conditions.

Acknowledgements. This research was funded by the ARC. We thank the staff and students from Heron Island Research Station, the Marine Botany Group and the Centre for Marine
Studies for assistance. In particular, we thank Dr. Selina Ward for help with methods, Dr. Adrian Jones for technical assistance, Dr. Ross Jones for use of equipment, Dr. Tim Carruthers for statistical advice and Grant Andrews for technical support. UMCES contribution no. 3127.

\section{LITERATURE CITED}

Ambarsari I, Brown BE, Barlow RG, Britton G, Cummings DG (1997) Fluctuations in algal chlorophyll and carotenoid pigments during solar bleaching in the coral Goniastrea aspera at Phuket, Thailand. Mar Ecol Prog Ser 159:303-307

Aro EM, Hundal T, Carlberg I, Andersson B (1990) In vitro studies on light-induced inhibition of photosystem II and D1-protein degradation at low temperatures. Biochim Biophys Acta 1019:269-275

Berkelmans R, Oliver JK (1999) Large-scale bleaching of corals on the Great Barrier Reef. Coral Reefs 18:55-60

Berkelmans R, Willis BL (1999) Seasonal and local spatial patterns in the upper thermal limits of corals on the inshore Central Great Barrier Reef. Coral Reefs 18:219-228

Björkman O, Demmig B (1987) Photon yield of $\mathrm{O}_{2}$ evolution and chlorophyll fluorescence characteristics at $77 \mathrm{~K}$ among vascular plants of diverse origins. Planta 170:489-504

Brown BE (1997a) Coral bleaching: causes and consequences. Coral Reefs 16(Suppl):S129-S138

Brown BE (1997b) Adaptations of reef corals to physical environmental stress. Adv Mar Biol 31:221-229

Brown BE, Dunne RP, Scoffin TP, Le Tissier MDA (1994) Solar damage in intertidal corals. Mar Ecol Prog Ser 105:219-230

Brown BE, Ambarsari I, Warner ME, Fitt WK, Dunne RP, Gibb SW, Cummings DG (1999) Diurnal changes in photochemical efficiency and xanthophyll concentrations in shallow water reef corals: evidence for photoinhibition and photoprotection. Coral Reefs 18:99-105

Brown BE, Dunne RP, Goodson MS, Douglas AE (2000) Marine ecology: Bleaching patterns in reef corals. Nature 404:142-143

Bruce D, Samson G, Carpenter C (1997) The origins of nonphotochemical quenching of chlorophyll fluorescence in photosynthesis. Biochemistry 36:749-755

Buss LW, Vaisnys JR (1993) Temperature stress induces dynamic chaos in a cnidarian gastrovascular system. Proc R Soc Lond Ser B 252:39-41

Coles SL, Fadlallah YH (1991) Reef coral survival and mortality at low temperatures in the Arabian Gulf: new species-specific lower temperature limits. Coral Reefs 9: 231-237

Coles SL, Jokiel PL (1977) Effects of temperature on photosynthesis and respiration in hermatypic corals. Mar Biol 43:209-216

Coles SL, Jokiel PL (1978) Synergistic effects of temperature, salinity and light on the hermatypic coral Montipora verrucosa. Mar Biol 49:187-195

Dana JD (1843) On the temperature limiting the distribution of corals. Am J Sci 45:130-131

Demmig-Adams B (1990) Carotenoids and photoprotection in plants. A role for the xanthophyll zeaxanthin. Biochim Biophys Acta 1020:1-24

Eisenhart C, Hastay MW, Wallis WA (1947) Techniques of statistical analysis. McGraw-Hill, New York

Endean R, Stephenson W, Kenny R (1956) The ecology and distribution of intertidal organisms on certain islands off the Queensland coast. Aust J Mar Freshw Res 7:317-342

Fang LS, Huang SP, Lin KL (1997) High temperature induces the synthesis of heat-shock proteins and the elevation of 
intracellular calcium in the coral Acropora grandis. Coral Reefs 16:127-131

Ferrier-Pages C, Schoelzke V, Jaubert J, Muscatine L, HoeghGuldberg O (2001) Response of a scleractinian coral, Stylophora pistillata, to iron and nitrate enrichment. J Exp Mar Biol Ecol 259(2):249-261

Fitt WK, Spero HJ, Halas J, White MW, Porter JW (1993) Recovery of the coral Montastrea annularis in the Florida Keys after the 1987 Caribbean bleaching event. Coral Reefs 12:57-64

Foyer C, Lelandis M, Kunert KJ (1994) Photoxidative stress in plants. Physiol Plant 92:696-717

Gates RD, Baghdasarian G, Muscatine L (1992) Temperature stress causes host cell detachment in symbiotic cnidarians: implications for coral bleaching. Biol Bull (Woods Hole) 182:324-332

Gleason DF, Wellington GM (1993) Ultraviolet radiation and coral bleaching. Nature 265:836-838

Glynn PW (1993) Coral bleaching: ecological perspectives. Coral Reefs 12:1-17

Glynn PW, D'Croz L (1990) Experimental evidence for high temperature stress as the cause of El Niño-coincident coral mortality. Coral Reefs 8:181-191

Glynn PW, Stewart RH (1973) Distribution of coral reefs in the Pearl Islands (Gulf of Panama) in relation to thermal conditions. Limnol Oceanogr 18:211-216

Greer DH (1990) The combined effects of chilling and light stress on photoinhibition of photosynthesis and its subsequent recovery. Plant Physiol Biochem 28:447-455

Greer DH, Laing WA (1991) Low-temperature and brightinduced photoinhibition of photosynthesis in kiwifruit leaves. Acta Hortic 297:315-321

Hoegh-Guldberg O (1989) The regulatory biology of plantanimal endosymbiosis. $\mathrm{PhD}$ thesis, University of California, Los Angeles

Hoegh-Guldberg O (1995) Temperature, food availability, and the development of marine invertebrate larvae. Am Zool 35:415-425

Hoegh-Guldberg O (1999) Climate change, coral bleaching and the future of the world's coral reefs. Mar Freshw Res 50:839-866

Hoegh-Guldberg O, Jones RJ (1999) Photoinhibition and photoprotection in symbiotic dinoflagellates from reefbuilding corals. Mar Ecol Prog Ser 183:73-86

Hoegh-Guldberg O, Smith GJ (1989a) The effect of sudden changes in temperature, light and salinity on the population density and export of zooxanthellae from the reef corals Stylophora pistillata Esper and Seriatopora hystrix Dana. J Exp Mar Biol Ecol 129:279-303

Hoegh-Guldberg O, Smith GJ (1989b) The influence of the population density of zooxanthellae and supply of ammonium on the biomass and metabolic characteristics of the reef corals Seriatopora hystrix (Dana 1846) and Stylophora pistillata (Esper 1797). Mar Ecol Prog Ser 57:173-186

Iglesias-Prieto R, Matta WA, Robins WA, Trench RK (1992) Photosynthetic response to elevated temperature in the symbiotic dinoflagellate Symbiodinium microadriaticum in culture. Proc Natl Acad Sci USA 89:10302-10305

IPCC (Intergovernmental Panel on Climate Change) (2000) Special Report on Emissions Scenarios. In: Nakicenovic N, Swart R (eds). Cambridge University Press, Cambridge

Jeffrey SW, Humphrey GF (1975) New spectrophotometric equations for determining chlorophylls a, b, c, and c2 in higher plants, algae and natural phytoplankton. Biochem Physiol Pflanz 167:191-194

Jokiel PL, Coles SL (1974) Effects of heated effluent on hermatypic corals at Kahe Point, Oahu. Pac Sci 28:1-18
Jokiel PL, Coles SL (1990) Response of Hawaiian and other Indo-Pacific reef corals to elevated temperature. Coral Reefs 8:155-162

Jones R (1997) Changes in zooxanthellar densities and chlorophyll concentrations in corals during and after a bleaching event. Mar Ecol Prog Ser 158:51-59

Jones RJ, Hoegh-Guldberg O (1999) Effects of cyanide on coral photosynthesis: Implications for identifying the cause of coral bleaching and for assessing the environmental effects of cyanide fishing. Mar Ecol Prog Ser 177:83-91

Jones RJ, Hoegh-Guldberg O (2001) Diurnal changes in the photochemical efficiency of the symbiotic dinoflagellates (Dinophyceae) of corals: Photoprotection, photoinactivation and the relationship to coral bleaching. Plant Cell Environ 24(1):89-99

Jones RJ, Yellowlees D (1997) Regulation and control of intracellular algae (= zooxanthellae) in hard corals. Phil Trans R Soc Lond B 352:457-468

Jones RJ, Hoegh-Guldberg O, Larkum AWD, Schreiber U (1998) Temperature-induced bleaching of corals begins with impairment of the $\mathrm{CO}_{2}$ fixation mechanism in zooxanthellae. Plant Cell Environ 21:1219-1230

Jones RJ, Kildea T, Hoegh-Guldberg O (1999) PAM chlorophyll fluorometry: A new in situ technique for stress assessment in scleractinian corals, used to examine the effects of cyanide from cyanide fishing. Mar Pollut Bull 38:864-874

Jones RJ, Ward S, Yang, Hoegh-Guldberg O (2000) Changes in quantum efficiency of Photosystem II of symbiotic dinoflagellates of corals after heat stress, and of bleached corals sampled after the 1998 Great Barrier Reef mass bleaching event. Mar Freshw Res 51(1):63-71

Kevin KM, Hudson RCL (1979) The role of zooxanthallae in the hermatypic coral Plesiastrea urvillei from cold waters. J Exp Mar Biol Ecol 36:1-23

Kleppel GS, Dodge RE, Reese CJ (1989) Changes in pigmentation associated with the bleaching of stony corals. Limnol Oceanogr 34:1331-1335

Krause GH (1992) Effects of temperature on energy-dependent fluorescence quenching in chloroplasts. Photosynthetica 27:249-252

Krause GH (1994) Photoinhibition induced by low temperatures. In: Baker NR, Bowyer JR (eds) Photoinhibition of photosynthesis: from molecular mechanisms to the field. BIOS Scientific Publishers, Oxford, p 331-348

Lesser MP (1996) Exposure of symbiotic dinoflagellates to elevated temperatures and ultraviolet radiation causes oxidative stress and inhibits photosynthesis. Limnol Oceanogr 41:271-283

Lesser MP (1997) Oxidative stress causes coral bleaching during exposure to elevated temperatures. Coral Reefs 16: 187-192

Lesser MP, Shick JM (1989) Effects of irradiance and ultraviolet radiation on photoadaptation in the zooxanthellae of Aiptasia pallida: primary production, photoinhibition and enzymic defences against oxygen toxicity. Mar Biol 102: 243-255

Lesser MP, Stochaj WR, Tapley DW, Shick JM (1990) Bleaching in coral reef anthozoans: effects of irradiance, ultraviolet radiation and temperature, on the activities of protective enzymes against active oxygen. Coral Reefs 8:225-232

Le Tissier MDA, Brown BE (1996) Dynamics of solar bleaching in the intertidal reef coral Goniastrea aspera at Ko Phuket, Thailand. Mar Ecol Prog Ser 136:235-244

Long SP, Humphries S, Falkowski PG (1994) Photoinhibition of photosynthesis in nature. Annu Rev Plant Physiol Plant Mol Biol 45:633-662 
Lyons JM (1973) Chilling injury in plants. Annu Rev Plant Physiol 24:445-466

Marshall PA, Baird AH (2000) Bleaching of corals on the Great Barrier Reef: differential susceptibilities among taxa. Coral Reefs 19:155-163

Mayer AG (1914) The effects of temperature on tropical marine animals. Pap Tort Lab, Carn Inst Wash 6:1-24

Muscatine L, Pool RR (1979) Regulation of numbers of intracellular algae. Proc R Soc Lond Ser B 204:131-139

Muscatine L, Grossman D, Doino J (1991) Release of symbiotic algae by tropical sea anemones and corals after cold shock. Mar Ecol Prog Ser 77:233-243

Muscatine L, Ferrier-Pages C, Blackburn A, Gates RD, Baghdasarian G, Allemand D (1998) Cell-specific density of symbiotic dinoflagellates in tropical anthozoans. Coral Reefs 17:329-337

Nobel PS (1991) Physicochemical and environmental plant physiology. Academic Press, San Diego

Öquist G, Anderson JM, McCaffery S, Chow WS (1992) Mechanistic differences in photoinhibition of sun and shade plants. Planta 188:538-544

Orr AP (1933) Physical and chemical conditions in the sea in the neighbourhood of the Great Barrier Reef. Sci Rep Great Barrier Reef Expedition 1928-29 2:37-86

Osmond CB (1994) What is photoinhibition? Some insights from comparisons of sun and shade plants. In: Baker NR, Bowyer JR (eds) Photoinhibition of photosynthesis: from molecular mechanisms to the field. BIOS Scientific Publishers, Oxford, p 95-110

Porter JW, Fitt WK, Spero HJ, Rogers CS, White MW (1989) Bleaching in reef corals: physiological and stable isotopic responses. Proc Natl Acad Sci 86:9342-9346

Rees TAV (1991) Are symbiotic zooxanthellae nutrient deficient? Proc R Soc Lond Ser B 243:227-233

Reimer AA (1971). Observations on the relationships between several species of tropical Zoanthids (Zoanthidae, Coelenterata) and their zooxanthellae. J Exp Mar Biol Ecol 7: 207-214

Richter M, Ruhle W, Wild A (1990) Studies on the mechanism of photosystem II photoinhibition. The involvement of toxic oxygen species. Photosynth Res 24:237-244

Roberts HH, Rouse LJ Jr, Walker ND, Hudson JH (1982) Coldwater stress in Florida Bay and Northern Bahamas: a product of winter cold-air outbreaks. J Sediment Petrol 52: 145-155

Editorial responsibility: Charles Birkeland (Contributing Editor), Honolulu, Hawaii, USA
Roberts L (1990) Warm waters, bleached corals (Caribbean). Science 250:213

Schreiber U, Bilger W (1987) Rapid assessment of stress effects on plant leaves by chlorophyll fluorescence measurements. In: Tenhunen J, Catarino FM, Lange OL, Oechel WC (eds) Plant response to stress. Springer-Verlag, Berlin, p $27-53$

Schreiber U, Neubauer C (1990) $\mathrm{O}_{2}$-dependent electron flow, membrane energization and the mechanism of nonphotochemical quenching of chlorophyll fluorescence. Photosynth Res 25:279-293

Schreiber U, Schliwa U, Bilger W (1986) Continuous recordings of photochemical and non-photochemical chlorophyll fluorescence quenching with a new type of modulation fluorometry. Photosynth Res 10:51-62

Shing FK, Wei LC, Chin LM (1995) Pigment composition in different-coloured Scleractinian corals before and during the bleaching process. Zool Stud 34:10-17

Smillie RM, Hetherington SE, He J, Nott R (1988) Photoinhibition at chilling temperatures. Austr J Plant Physiol 15: 207-222

Steen RG, Muscatine L (1987) Low temperature evokes rapid exocytosis of symbiotic algae by a sea anemone. Biol Bull (Woods Hole) 172:246-263

Urban FE, Cole JE, Overpeck JT (2000) Influence of mean climate change on climate variability from a 155-year tropical Pacific coral record. Nature 407:989-993

Vaughan TW (1918) The temperature of the Florida reef tract. Pap Tort Lab, Carn Inst Wash 31:321-339

Ward S (2000) Changes in coral reproduction following slight changes in temperature. Proc JAMSTEC Int Coral Reef Symp. Tokyo, Japan

Watson PF, Morris GJ (1987) Cold shock injury in animal cells. Symp Soc Exp Biol 41:311-340

Wells JW (1952) The coral reefs of Arno Atoll, Marshall Islands. Atoll Res Bull 9:14

Williams EHJ, Bunkley-Williams L (1990) The world-wide coral reef bleaching cycle and related sources of coral mortality. Atoll Res Bull 335:1-71

Yonge CM, Nicholls AG (1931) Studies on the physiology of corals. IV. The structure, distribution, and physiology of the zooxanthellae. Sci Rep Great Barrier Reef Expedition 1928-29:135-176

Zar JH (1984) Biostatistical analysis, 2nd edn. Prentice-Hall, Englewood Cliffs, NJ

Submitted: August 20, 2001; Accepted: September 17, 2002

Proofs received from author(s): January 20, 2003 